\title{
The Utilization of Medicinal Plants for Diabetes Mellitus Dayak Ngaju Ethnic at Tumbang Samba in Central Kalimantan
}

\author{
Helsi Fujianti ${ }^{1}$ Nanik Lestariningsih ${ }^{1, *}$ Ridha Nirmalasari ${ }^{1}$ \\ ${ }^{I}$ Tadris Biologi, Fakultas Tarbiyah dan Ilmu Keguruan IAIN Palangka Raya, Palangka Raya 73111, Indonesia \\ * Corresponding author. Email: nanik.lestariningsih@iain-palangkaraya.ac.id
}

\begin{abstract}
The Dayak Ngaju is the largest ethnic in Central Kalimantan whose existence is spread over several watersheds and very close to nature (forests). It has been a long time since people have traditionally used or made use of various types of plants to treat Diabetes mellitus. The utilization of plant species as medicine is used by the community from generation to generation. Most of these medicinal plants are obtained from the forest or yard. This study aimed to determine the types of plants used, the parts of plant organs used, and how to use plants with the medicinal properties of Diabetes mellitus by the Dayak Ngaju ethnic in Tumbang Samba, Central Kalimantan. This research belonged to a qualitative method with a descriptive exploratory. The data was collected by using observation, interview, and direct documentation to the field where the plants were located. The informants in this study were Battra and people who know about medicinal plants. The research is located in Samba Katung, Tumbang Samba Village, Katingan Tengah District, Katingan Regency, Central Kalimantan Province. The results showed that 23 types of plants are used as ingredients for Diabetes mellitus. The parts of plant included roots $(36 \%)$, stems $(6 \%)$, bark (13\%), seeds $(3 \%)$, and leaves $(42 \%)$. The most widely used parts of the plant are the roots and leaves. The utilization or processing of medicinal plants by the Dayak Ngaju ethnic by boiling (50\%), soaking (10\%), pounding (34\%), dipping (3\%), and stirring fry (3\%). The method of processing that most widely used is by boiling it.
\end{abstract}

Keywords: Dayak Ngaju, Diabetes mellitus, Medicinal Plants

\section{INTRODUCTION}

According to [1] Kalimantan is an island in Indonesia which is famous for its knowledge of traditional medicine using plants that are passed down orally from generation to generation. The use of medicinal plants is unique and in certain areas varies from other regions, both how to make potions and how to use them and some even link them to myths. The biological wealth that has been collected in various types of ecosystems has been widely used to meet the daily needs of traditional communities in meeting their food, clothing, shelter, medicine and spiritual needs. One of them is the use of plants as medicinal ingredients by various indigenous tribes or groups of people living in the interior. The traditions and knowledge of rural local communities about the use of medicinal plants cannot be separated from the local culture that has lasted a long time [2].

People believe that medicinal plants can cure various diseases, one of which is Diabetes mellitus. It also known as diabetes has been known since approximately two thousand years ago. At that time two Greek health experts, Celcus and Areteus, gave the name or designation of diabetes to people who suffered from a lot of drinking and a lot of urination. Therefore, until now the patient drinks a lot and a lot of urine is known in the medical world as Diabetes [3].

The Dayak Ngaju ethnic community in Tumbang Samba is one of the ethnic groups that still uses plants as traditional medicine. Sub group ethnic of Dayak Ngaju the ethnic Paramasan, Meratus, Seruyan, Katingan, Banjar Hulu, Bakumpai, Wehea, and Jangkang Tanjung [4]. Tumbang Samba is a village located in Katingan Tengah sub-district, Katingan district, Central Kalimantan. Tumbang Samba is further divided into several villages along the watershed including Samba Bakumpai, Samba Katung, Samba Danum, and Samba Kahayan. The Dayak Ngaju ethnic uses plants that they get from the forest and around the yard as traditional medicine. How to use and the ingredients taken are different. As well as various parts of the plant taken from the fruit, 
leaves, roots and bark. From some of the plants used, it is believed that they can cure several diseases such as Diabetes mellitus. So, it is also necessary to do further research on The Utilization of Medicinal Plants for Diabetes mellitus Ngaju Tribe in Tumbang Samba, Central Kalimantan.

This study aims to determine types of plants used, parts of organs plant used, and to know how to use plants with the medicinal properties of Diabetes mellitus by Dayak Ngaju tribe in Tumbang Samba, Central Kalimantan.

\section{MATERIALS AND METHODS}

The research was conducted in Samba Katung, Katingan Tengah District, Katingan Regency, Central Kalimantan from July to August 2020. This research belonged to a qualitative research design with exploratory research type. The population of this study were battra and people who familiar about the medicinal herbs for Diabetes mellitus. A traditional healer (battra) is someone who is recognized and utilized by the community as a person capable of performing traditional medicine. The sample of the research was medicinal plants obtained from interviews with Battra. The technique of data collection was carried out namely; observation, interviews, and direct documentation where the plants were located. Techniques for the validity of research data were given to experts in assessment and decision-making including interview instruments, as well as descriptions of plants. The data analysis technique was descriptive techniques. The tools of this research were complete writing instruments and a camera. While, the material used is a structured interview questionnaire. Interviews were conducted on informants battra and native residents of the Samba Katung. Interviews were conducted to study plants as traditional Diabetes mellitus medicines used by the Dayak Ngaju ethnic, starting from the types of plants used, parts of plants taken as medicine, and how to use plants as medicines for Diabetes mellitus.

\section{RESULT AND DISCUSSION}

\subsection{Discussion}

The results of this research on the use of plants with the medicinal properties of Diabetes mellitus for the Dayak Ngaju ethnic in Samba Katung obtained 23 species of plants consisting of 13 names of family (Table 1).

Table 1. Types, parts of plants, and how to use plants used as medicine for Diabetes mellitus by the tribe of Dayak Ngaju in Samba Katung village

\begin{tabular}{|c|c|c|c|c|c|c|}
\hline No & Local Name & Spesies & Family & Parts of Used & Processing Method & The use \\
\hline 1 & Sungkai Wood & Albertisia papuana Becc. & Lamiaceae & Root & Boiled and soaked & Drunk and bathed \\
\hline 2 & Pangalit Wood & Jatropha multifida $\mathrm{L}$ & Jatropha & $\begin{array}{l}\text { Root, stems, } \\
\text { and leaves }\end{array}$ & Pounded and boiled & Smeared and drunk \\
\hline 3 & $\begin{array}{l}\text { Bajakah } \\
\text { Kalalawit }\end{array}$ & Uncaria gambir roxb & Fabaceae & Stems & Boiled & Drunk \\
\hline 4 & Sangeh Wood & - & - & Root and bark & Boiled and soaked & Drunk and washed \\
\hline 5 & Nanasian Wood & - & Lamidaceae & Root and leaves & Boiled and pounded & Drunk and smeared \\
\hline 6 & Halaban Wood & Vitex pinnata $\mathrm{L}$ & Verbenaceae & Leaves and bark & Pounded and boiled & Smeared and drunk \\
\hline 7 & Karamunting & $\begin{array}{l}\text { Rhodomyrtus tomentosa } \\
\text { (Aiton) Hassk }\end{array}$ & Myrtaceae & Leaves & Pounded and boiled & Smeared and drunk \\
\hline 8 & Tabalien Wood & Eusideroxylon zwageri & Lauraceae & Leaves and bark & Pounded and boiled & $\begin{array}{l}\text { Drunk, bathed and } \\
\text { smeared }\end{array}$ \\
\hline $\begin{array}{c}9 \\
10\end{array}$ & $\begin{array}{l}\text { Pucuk Putat } \\
\text { Lancar Kuning }\end{array}$ & $\begin{array}{l}\text { Planchonia valida } \\
-\end{array}$ & $\begin{array}{l}\text { Lecythidaceae } \\
-\end{array}$ & Leaves & Pounded & Smeared \\
\hline 11 & $\begin{array}{l}\text { Kamasulan } \\
\text { Wood }\end{array}$ & Pternandra rostrata & Lauraceae & Leaves & Pounded & Smeared \\
\hline 12 & $\begin{array}{l}\text { Jambu } \\
\text { Karantukal Wood }\end{array}$ & Psidium guajava $\mathrm{L}$ & Myrtaceae & Leaves and bark & $\begin{array}{l}\text { Pounded, boiled and } \\
\text { soaked }\end{array}$ & Brushed and bathed \\
\hline 13 & Pinang & Areca catechu $\mathrm{L}$. & Arecaceae & Root & Boiled & Drunk \\
\hline 14 & Enyuh & Cocos nucifera $\mathrm{L}$ & Arecaceae & Root & Boiled & Drunk \\
\hline 15 & Tingen & Imperata Cylindrical (L) & Poaceae & Root & Boiled & Drunk \\
\hline 16 & Insulin & $\begin{array}{l}\text { Gymnanthemum } \\
\text { amygdalinum }\end{array}$ & Asteraceae & Leaves & Dipped & Drunk \\
\hline 17 & $\begin{array}{l}\text { Kumis Kucing } \\
\text { Bawi Hatue }\end{array}$ & Orthosiphon spicatus B.B.S & Labiatae & Root & Boiled & Drunk \\
\hline 18 & Lombok Liau & Physalis angulata $\mathrm{L}$ & Solanaceae & Root & Boiled & Drunk \\
\hline 19 & Kangkala & Litsea angulata & Lauraceae & Seed, & Stir fry & Eaten \\
\hline 20 & Kalampait & Clerodendrum japonicum & Verbenaceae & $\begin{array}{l}\text { Roots and } \\
\text { leaves }\end{array}$ & Pounded and boiled & Smeared and drunk \\
\hline 21 & Pucuk Patindis & - & Myrtaceae & Leaves & Pounded & Smeared \\
\hline 22 & Perun Petak & Mentha aquatica & Lamiaceae & Leaves & Pounded & Smeared \\
\hline 23 & Gambir & $\begin{array}{l}\text { Uncaria Gambir (Hunter) } \\
\text { Roxb }\end{array}$ & Rubiaceae & Root & Boiled & Drunk \\
\hline
\end{tabular}


Parts of plants are used by the Dayak Ngaju ethnic of Samba Katung as medicinal ingredients consist of roots, stems, bark, leaves, and seeds. The most widely used part of the plant was the roots with a percentage of $42 \%$ and the least was the part of the seeds with a percentage of $3 \%$ (Figure 1).

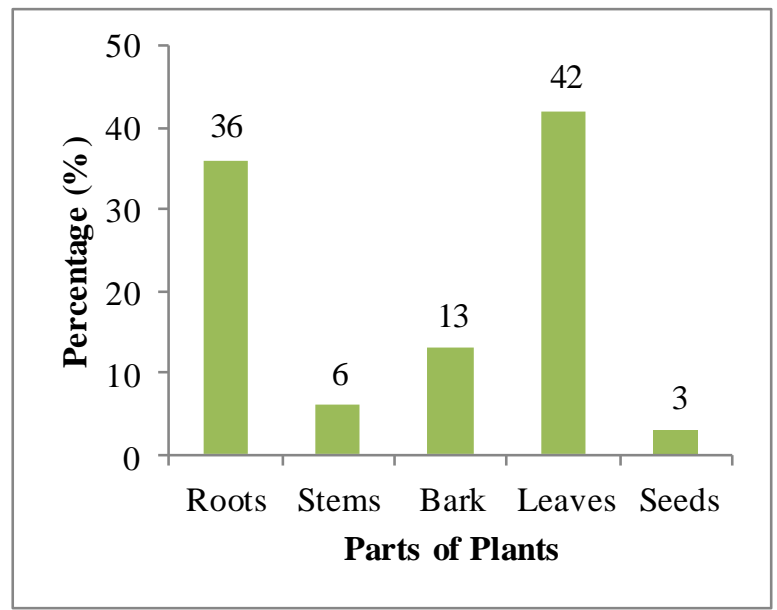

Figure 1. Percentage of Parts of Medicinal Plants Used by the Dayak Ngaju ethnic of Samba Katung

The method of preparation or processing of medicinal plants by the Dayak Ngaju ethnic of Samba Katung is done by boiling, soaking, pounding, dipping and stirring fry. The most widely used method is boiling with percentage of $50 \%$ and the least method is dipping and stirring fry with a percentage of $3 \%$ (Figure 2 ).

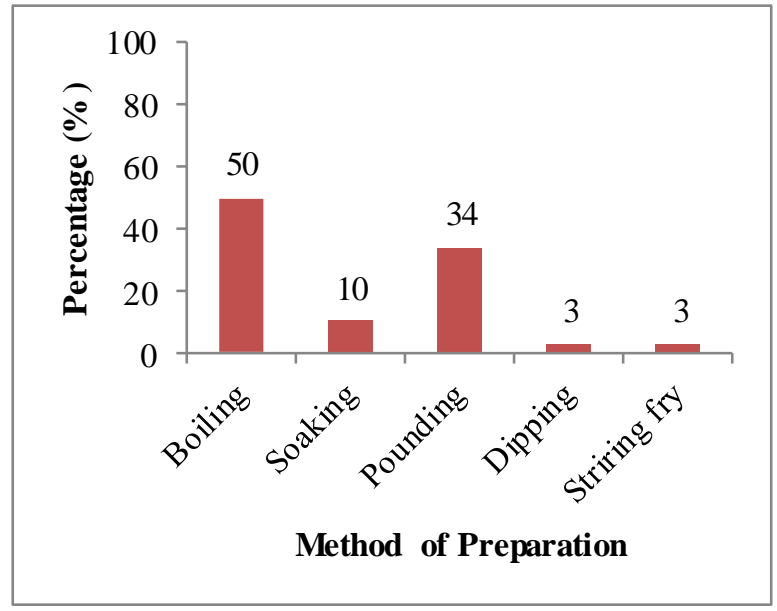

Figure 2. Percentage of preparation method on Medicinal Plant Used by the Dayak Ngaju Tribe of Samba Katung Village

\subsection{Discussion}

The number of medicinal plants used by the Dayak Ngaju ethnic of Samba Katung Village is 23 species belonging to 13 names of family. Albertisia papuana Becc. (Sungkai wood) is a plant that has a shrub in the form of shrubs, a taproot, the true stem type, the growing upright, the shape of a round bone, the surface of the trunk is rough, the colour of the stem is greenish black. The type of leaf is incomplete because it only has (petiole and blade leaf), elongated blade leaf, fanged tip leaf, rounded base leaf, flat edge leaf, smooth blade surface leaf, pinnate arrangement leaf, leaves are dealing criss-cross [5].

Jatropha multifida L (Pangalit wood) is a plant that has a shrub or small tree with a single trunk, a loose crown spreading and up to $5 \mathrm{~m}$. The blade leaf is divided into 7-15 small fingers. The colour is dark green on the upper surface and lighter on the lower surface. The inflorescences form coral gathered supported by long stalks. This plant has a round fruit like nuts, and the colours is yellow when ripe [6].

Uncaria gambir roxb (Bajakah kalalawit) is a tree with a height of $2-5$ meters. The tree has riding roots, the stem is brown with a sympodial branching pattern, with single leaf glossy green, flat leaf edge with pinnate leaf type, leaves are dealing criss-cross. The leaf diameter is $5-8 \mathrm{~cm}$ and the width is $3-5 \mathrm{~cm}$.

Sangeh wood is a plant with tree habitus that has a taproot shape, a round trunk, monopodial branching, and grows upright. The leaf is single shape leaf, smooth leaf surface, it has a strong leaf bone and no flowers and fruit. The sangeh plant is a perennial plant and its habitat can be found in the peatlands. Sangeh plants can growth of $25 \mathrm{~m}$ high.

Nanasian wood is a plant with shrub habitus by reaching 2-4 meters high. It has a taproot shape, a small hairy brown trunk, sympodial branching, and grows upright. The leaf has a single leaf shape, hairy leaf surface, a strong leaf bone, and no flowers and fruit. Nanasian plants are perennials and their habitat can be found in peatland forests.

Vitex pinnata $L$ (Halaban wood) is a tree with a height of $\pm 25 \mathrm{~m}$, with a trunk diameter of $35-45 \mathrm{~cm}$. This tree has many branches that are not straight / bent irregularly. Laban wood is quite hard, dense, straight grain, alternating yellow brown and dark brown. The leaf is dealing each other generally 3-5 leaves. The leaf has a shape round eggs to oval / elliptical, tapering to the tip and base of the leaf. Inflorescences are found at the end of the stem or in the axillary of the leaves, the colour of the flower is blue but the inside is slightly purple. The fruit includes stone fruit, round shape and a little water [7]. 
Rhodomyrtus tomentosa (Aiton) Hassk (Karamunting) is a habitus shrub. It has a single leaf that is elliptical, extending to oval. The leaf is dealing each other or scattered, flat edges, hairy leaf surface, when touched feels rough. It also has an irregular flowers reddish purple, small protective leaves, attached petals, tubular, located on top of the elongated ovule, 3-5 flower crown. The crown leaves are loose or attached like a cup. The fruit will sink or half drown, bear 1 to many, pistil 1 . Buni fruit, stone fruit, box fruit or hard fruit. The fruit is small and the colour is dark blue to black and edible, the seeds are small and the colour is orange [5].

Eusideroxylon zwageri (Tabalien wood) belongs to the tree habitus or taproot. The stems grow straight up to $150 \mathrm{~cm}$ in diameter and $30-50 \mathrm{~m}$ high. The Ulin tree can reach a height of $4 \mathrm{~m}$, the bark is reddish brown with $2-9 \mathrm{~cm}$ thick and has a smooth texture, the crown is round, dense, and has horizontal branching. The leaves of the Ulin tree are arranged in a spiral, a single with flat edge in the shape of ellipse to round with tapered leaf tips and have a length of $14-18 \mathrm{~cm}$ and a width of $5-11 \mathrm{~cm}$. The Ulin flowers are quickly decay greenish, yellow or purple, symmetrical in all directions with a length of 2-3 $\mathrm{mm}$. The Ulin tree fruit is an elliptical to round stone fruit with one seed with a length of $7-16 \mathrm{~cm}$ and a diameter of 5-9 cm. The pulp is gummy, smooth, and clear. In one Ulin fruit, there is one seed with a length of 5-15 cm and a diameter of 3-6 cm. The Ulin seed bark is very hard and grooved light brown. The Ulin seeds have vary in weight between 45-360 g / grain.

Planchonia valida (Pucuk Putat) is a Putat plant with shrub habitus with a height of 2-3 meters. It has a taproot shape, a reddish green stem, monopodial branching, and grows upright. The leaf is single shape leaf, smooth surface leaf, a strong leaf bone, and the length can reach about $40 \mathrm{~cm}$ and width 10 $\mathrm{cm}$. This plant has no flowers and fruit. Putat is a perennial plant and its habitat can be found in wet peatland forests.

Lancar Kuning is a plant with shrub habitus with a height of 2-3 meters. It has a taproot shape, brown stems, monopodial branches, and grow upright. The type of leaf is compound shape leaf with pinnate leaf, and has a strong leaf bone. This plant has no flowers and fruit. The habitat of Lancar Kuning plants can be found in yards and forests.

Pternandra rostrata (Kamasulan) wood is a plant with tree habitus. This plant can growth up to 10-20 $\mathrm{m}$ high. The plant has roots are riding, the stem grows upright with a trunk diameter of $20-25 \mathrm{~cm}$. the leaf is single leaf parallel, scattered, leaves are dealing each other, and flat leaf edges.
Psidium guajava L (Quarantined Guava Wood) has branching roots with a long tapering shape and will grow straight into the ground. The stem is hard and elongated and has a smooth surface. The ripening is round with a diameter about $10-20 \mathrm{~cm}$ or more. This plant has a single pinnate leaf, leaves are located and dealing each other, short-stemmed, young leaves with fine hair and the upper surface of the leaves looks old and smooth. The tip of the leaf is blunt, the upper part of the leaf is greener than the lower side of the leaf with a cylindrical stalk and does not thicken at the stem. Guava flowers are generally white, reddish in colour and accompanied by two crowns that have 4-5 petals in one crown. The fruit is round and slightly yellowish green. Guava fruit is thick enough when the fruit is ripe, the colour inside is white and the outside is slightly yellowish green. While, there are quite a lot of guava seeds and sprinkled in the middle of the fruit flesh. The seeds are quite hard and have a slightly brownish yellow colour.

Areca catechu L. (Pinang) habitus. This tree has a fibrous root system, brown in colour, slender trunk, growing upright, not branched, and with loose leaf marks. The leaves are pinnate compound, grow together at the end of the stem to form a stem rosette. The fruit is green when in early and yellow or reddish when old and the seeds are brown to reddish brown.

Cocos nucifera L. (Coconut) has a single stem, but sometimes branches. The coconut tree height can reach more than $30 \mathrm{~m}$ with a trunk diameter of $20-30$ $\mathrm{cm}$. the roots of coconut tree are fibrous, thick, woody, forming a hump, the depth of roots can get into the ground up to 8 meters and spread horizontally up to 16 meters. The leaves are arranged in a compound, single parallel pinnate, yellowish when in early and dark green when old. The coconut leaf strands are arranged on the right and left of the midrib firmly attached to the stem. The frond length can reach 8 meters and 65 pairs of leaves for mature coconut plants. Early leaves or coconut plant leaves are yellow and when they are old, they are green [8].

Imperata Cylindrical (L) (Tingen) is a shrub habitus which is a chronic grass type with long, scaly shoots and creeping underground. This plant has the tip (shoot) of spiky shoots, sharp like thorn mines that appear on the ground, short stems, rises above the ground, and ranges from $0.2-1.5 \mathrm{~m}$ high. The flowers have hair under the grain which is purplish red. The leaf is single lanceolate leaf, flat edge, tapered tip, base narrow, length $\pm 1 \mathrm{~m}$, width $\pm 1.5 \mathrm{~cm}$, white. The roots of the fibbers are dirty white [5].

Gymnanthemum amygdalinum (Insulin) can grow up to of 7-10 m height with a tap root system. The stems are straightening, the colours are gray and 
slightly brown. It has quite a lot of branching, but the branches are not so conspicuous because apart from not being too long, the condition is also brittle. The color of the branches of African leaves is green and sometimes a little brown when they are old. The leaf stems are actually woody stems with a round cross section. When the plant is old, the colour of the stems will turn dirty brown. Leaves with a pinnate system that grow directly / attach to the stem are slightly oval in shape about $10-15 \mathrm{~cm}$ high and $4-5 \mathrm{~cm}$ wide. The leaves are clearly visible and the bones are in the middle. The edges of the leaves are serrated and green. At the time of observation, neither flowers nor fruit were found on the plant.

Orthosiphon spicatus BBS (Kumis Kucing) habitus in the form of shrubs. It includes plants that grow upright in a height of up to $2 \mathrm{~m}$ with rooted nodes, rectangular stems with slightly grooved, short hair, single leaves, lanceolate, oval (similar to a rhombus), ovate, fine fur, serrated leaf edges coarse and irregular, leaf surface has spots, leaf length is between $1-10 \mathrm{~cm}$ and $7.5 \mathrm{~mm}-5 \mathrm{~cm}$ wide, and flowers are compound flowers in bunches that come out in end of the fork. The colour is mauve or white, while the stamens are longer than the flower tube. The fruit in the form of fruit boxes and ovate, this plant can be propagated by seeds or stem cuttings [5].

Physalis angulata L (Lombok Liau) is a seasonal herb with a height of 0.1-1 meter. It an upright trunk, sharp branches, forms a rectangle and has a cavity inside the stem. Leaves oval-shaped elongated, with a pointed tip, flat or not, with a size of $5-15 \mathrm{~cm} \mathrm{x}$ $2.5-10.5 \mathrm{~cm}$. This flower included Hermaphrodite, consisting of flower jewellery, pistils and stamens. The fruit is contained in a wrapper of inflated petals in the shape of an egg with a tapered light yellowish green colour, with purplish ribs about $2-4 \mathrm{~cm}$ long. The fruit inside is round and elongated, measuring between $1.5-2 \mathrm{~cm}$ and a yellowish colour when ripe. Ciplukan seeds have a white colour when the fruit is still early growth enough, while when the fruit is ripe the seeds will turn brown. In general, the number of seeds in each fruit is 129-207 depending on the size of the fruit [9].

Litsea angulata (Kangkala) is a perennial (paranual) tree. It is a tree with a height of 10-20 m. This tree has a taproot, the stem grows upright, the branching is rarely too tight. The leaf is a single with large size and elongated shape leaf. The fruit is round, soft fruit bark, half of the fruit is covered by hard green fruit petals. Young fruit bark is green and red when ripe. This tree has white soft flesh, seeds are round and hard brown. Sometimes, the fruit is seasonal, so it is only found at certain times [10].
Clerodendrum japonicum (Kalampait) has stalks covered with fine bristle, single-leaf, stemmed, round fruit, and dealing each other. The leaves are ovalshaped widened with the base of the leaf like a heart and can growth up to $30 \mathrm{~cm}$ in length. The colour is red, consisting of small flowers that gather and come out of the end of the stalk. It has a reddish-brown taproot that leads into the ground. Kalampait including annual shrubs plant with a height of 1-3 meters.

Pucuk Patindis is a plant with shrub habitus with a height of 2-3 meters. It has a taproot shape, a greenish stem, monopodial branching, and grows upright. The leaf is a single leaf form, a petiole and strong leaf bone. It also has no flowers and fruit. Pucuk Patindis plants are perennials and their habitat can be found in wet peatland forests.

Mentha aquatica (Perun Petak) belongs to the Lamiaceae family of plants from the mint tribe so that it has a distinctive smell of each species. Plants in this family are generally in the form of herbs and shrubs, which mostly provide ground cover. The stems and branches are rectangular, the leaves are deal each other or cross facing, do not have a supporting leaf. The compound flower's petals do not fall, around 4-5, the flower crowns are attached in the shape of lips [11].

Uncaria Gambir (Hunter) Roxb (Gambir) is a climbing shrub. Plant stems are cuboid or cylindrical, irregular and hairless. It has sympodial branching and the surface of the stem is light brown to reddish brown. The leaf is single leaf grows on the stem, elongated oval with tapered leaf tips and serrated leaf edges. The surface of the leaves is hairless or smooth, equipped with short petioles. Gambier leaf length is about $8-13 \mathrm{~cm}$ with a width of $4-7 \mathrm{~cm}$. The leaves are dealing criss-cross and the lower leaves are prominent. The compound interest is shaped like a bell and grows in the armpits of the leaves. The flower size is about $5 \mathrm{~cm}$. There are 5 flower crowns are oval and the colour is purple, the flower is short petals and five stamens. The fruit pseudo pods with a cross section of up to $2 \mathrm{~cm}$ filled with fine seeds measuring $\pm 1-2 \mathrm{~mm}$. The outer part of the seed has wings that allow the seeds to spread out due to the wind. Many seeds are shaped like needles and small and the colour is yellow [12].

The parts of plants most widely used as medicine are the roots and leaves. According to the informant's avowal, based on interviews, the parts of the plant that most often used as a medicine for diabetes mellitus are the roots and leaves because it seen from this type of disease that causes wounds so as to heal the outside, using the leaves as an ointment and some for drinking. Meanwhile, to heal the inside, the roots 
of plants are used more. [13-14] stated that the use of leaves has no a major influence on the growth of a species and a negative impact on plant survival. Leaves have the most chemical content. According to [15], the presence of secondary metabolites is mostly in the leaves because the photosynthesis process occurs in the leaves.

The method of preparation or utilization for diabetes mellitus medicinal plants carried out by the Dayak Ngaju Tribe in Samba Katung, Tumbang Samba Village, Central Kalimantan. There are 5 ways of processing method namely boiling, soaking, pounding, dipping, and stirring fry. The plant of preparation method most widely used by the Dayak Ngaju Tribe in Samba Katung, Tumbang Samba Village, Central Kalimantan is by boiling. According to [16] the boiling process can remove substances contained in plants compared to burning. This is in accordance with [17] which states that the higher the temperature, the greater the solubility of a substance.

\section{CONCLUSION}

The Dayak Ngaju Tribe in Samba Katung use medicinal plants as diabetes mellitus medicine consisting of 23 species and 13 name of family, namely: Albertisia papuana Becc., Jatropha multifida L, Uncaria gambir roxb, Sangeh wood, Nanasian wood, Vitex pinnata L, Rhodomyrtus tomentosa (Aiton) Hassk, Eusideroxylon zwageri, Pucuk putat, Lancar Kuning, Kamasulan wood, Psidium guajava L, Areca catechu L., Cocos nucifera L., Imperata Cylindrical (L), Gymnanthemum amygdalinum, Orthosiphon spicatus BBS, Physalis angulata L, Litsea angulata, Clerodendrum japonicum, Pucuk Patindis, Mentha aquatica Gambir (Hunter) Roxb. Parts of plant organs used are roots, stems, bark, leaves and seeds. The most widely used part of the plant was roots with a percentage of $42 \%$ and the least was the part of the seeds with a percentage of $3 \%$. The method of preparation or processing of medicinal plants is done by boiling, soaking, pounding, dipping and stirring fry. The most widely used method is boiling with a percentage of $50 \%$ and the least method is dipping and stirring fry with a percentage of $3 \%$.

\section{REFERENCES}

[1] Noorcahyati, Medicinal efficacious plants for ethnic indigenous Kalimantan, Research Institute for Natural Resources Conservation Technology, Ministry of Forestry Research and Development Agency, Balikpapan, 2012.

[2] R.V. Garvita, Pemanfaatan tumbuhan obat secara tradisional untuk memperlancar persalinan oleh Suku Dayak meratus di Kalimantan Selatan, Warta Kebun Raya (SemiPopular Magazine) 13(2) (2017) 51-58. [In Bahasa Indonesia]

[3] Lanywati, Endang, Diabetes mellitus, Diabetes. Yogyakarta, Kanisius, 2001. [In Bahasa Indonesia]

[4] H. Johan, U. Hairah, E. Budiman, Ethnobotany database: exploring diversity medicinal plants of Dayak tribe Borneo, In: 2017 4th International Conference on Electrical Engineering, Computer Science and Informatics (EECSI), 2017, pp.1-6. IEEE.

[5] Ibrahim, Inventory of traditional medicinal plants of the Bakumpai Dayak Community in Murung Raya, Undergraduate Thesis, IAIN Palangka Raya, 2016.

[6] J.F. Suwandi, I. Yunidasari, Literature study of flavonoid secondary metabolite ability from Chinese Jatropha stems (Jatropha multifida L), In: Increasing Platelet Levels of Dhf Patients, Jurnal Majority 5(3) (2016) 96-99.

[7] S.D. Yolanda, Biomass gasification (laban wood powder) updraft system single gas outlet with straw filter cleaning system (overview of straw filter performance on syngas production), Doctoral Dissertation, Politeknik Negeri Sriwijaya, 2015.

[8] D.F.N Azizah, Utilization of coconut tree bark as a toothache relief mouthwash, 2016.

[9] H.M. Tambunan, Exploration, Identification and morphological characteristics of Ciplukan (Physalis angulata L) in Karo, 2018.

[10] S. Susi, Identification of chemical components of Kalangkala Fruit and Binda as food material, 2020.

[11] I.R. Puspita, Ethnomedicine study on community in Benteng Gajah Village, Tompo Bulu District, Maros Regency, Doctorral Dissertation, Universitas Islam Negeri Alauddin Makassar, 2019.

[12] Agrotek Id, Klasifikasi dan morfologi tanaman gambir, Accessed on 26 October 2020, Link: https://Agrotek.Id/Klasifikasi-Dan-MorfologiTanaman-Gambir/ [In Bahasa Indonesia]

[13] I. Fakhrozi, ethnobotany of traditional malay tribe communities around the Bukit Tigapuluh National Park, Fakultas Kehutanan Institut Pertanian Bogor, 2009.

[14] D. Haryono, E. Wardenaar, F. Yusro, Ethnobotany study of medicinal plants in 
Mengkiang Village, Sanggau Kapuas District, Sanggau Regency, Jurnal Hutan Lestari 2(3) (2014) 427-434.

[15] L.R. Sjahid, Isolation and identification of flavonoids from Dewandaru leaves (Eugenia uniflora L.), Undergraduate Thesis, Fakultas Farmasi Universitas Muhammadiyah, Surakarta, 2008.

[16] J. Syah, Fh. Usman, F. Yusro, Ethnobotany study of medicinal plants utilized by the Nekbare hamlet, Babane Village, Samalantan District, Bengkayang Regency, Jurnal Hutan Lestari 2(3) (2014) 419-426.

[17] R. Voight, Pharmaceutical technology textbooks, Fifth Edition, Gadjah Mada University Press, Yogyakarta, 1994. 